\title{
A Strategy to Strengthen the US Economy*
}

\author{
Khalid Mehtabdin, Greg Hayes \\ The College of Saint Rose, Albany, USA
}

\begin{abstract}
For decades, the United States' competitive position in global manufacturing has steadily declined. Analysts point to increasingly automated manufacturing processes, changing domestic demand factors, outsourcing, and over confidence in service export surpluses. However, Asian and European competitors, undergoing the same pressures, have been able to maintain a healthy percentage of their GDP in manufacturing by growing high tech jobs while the United States continues to fall behind. Perhaps the most fundamental and overlooked contribution to this decline is the lackluster performance of the United States education system. After comparing the performance of US students to that of the other G-8 nations in the critical disciplines of math and science literacy, US students rank last. Furthermore, the most recent PISA test results show US students rank in the bottom half of 30 participating nations in the ability to apply math and science concepts to real world problems. This is particularly troubling when one considers that among the compared nations, the US spends the most on math and science teacher compensation. If the US intends to successfully compete in the global manufacturing arena, significant changes to the education system must be enacted. A new strategy aligning the system with real world demands should begin with a national initiative to increase Pre-K enrollments, a paradigm shift from liberal arts to math, science, problem solving and critical thinking, standardized policies aligning high school graduation requirements with college and work place expectations, and standardized college and career readiness assessment programs. These steps combined with more rigorous secondary education teacher certifications, continued education and involvement with universities and manufacturing firms within the community, should more adequately prepare high school students for further study or to enter the skilled workforce. At the post secondary level, federal and state funding should be targeted to R\&D programs specificly to industrial design, engineering, and alternative energy. Industry investment in such programs should be federally incentivized to foster cooperative relationships between business and academia. Such relationships will ensure faculty spend time focusing on how their discipline relates to manufacturing and instilling the necessary skill sets, knowledge and abilities which graduates will need to compete in the global market. Such a revised system will position the US to create and keep high paying manufacturing positions on its way to sustainable economic growth.
\end{abstract}

Keywords: jobs, technology, research/development

\footnotetext{
* Presented at the 2010 Annual Convention of the Pennsylvania Economic Association, Grove City, PA. Khalid Mehtabdin, Ph.D., School of Business, The College of Saint Rose.

Greg Hayes, MBA, School of Business, The College of Saint Rose.
} 


\section{Objective}

The events of the last two years have proven to be a powerful reminder of the potential danger of reliance on a predominantly service based economy to provide sustainable economic growth. The stark reality of our economy's fragile state, while frightening, may allow for a more open discussion on how to best restore the United States' position as the global manufacturing leader after decades of decline. It is no coincidence that as our competitive position in global manufacturing has declined, so too has the United States' performance in math, technology and science education, disciplines integral to maintaining a competitive edge in manufacturing. Deliberate funding in these critical disciplines, in conjunction with targeted private sector investment designed to create well paying jobs, are the first steps towards increasing the US GDP attributed to manufacturing from an anemic $12.7 \%$ to a level on a par with European and Asian competitors enjoying ranges above 20\% (Raveche, 2009). However, these steps alone cannot be successful without a renewed commitment across educational institutions to focus their programs on product innovation and bringing American goods to the global market.

\section{Existing Situation}

In the period following World War II, more than one third of jobs in America were in manufacturing, and by 1970, this number dropped to 25\%. In the ten year period from 1998 to 2008, more than 5 million jobs were lost, and since President Barack Obama took office in 2009 and additional 1.1 million jobs have been shed (Bornemann, 2009). Today just roughly 9 percent of all American jobs are in this sector (Kanell, 2009). Perhaps a further $4 \%$ of those employed in manufacturing are employed in service oriented jobs such as financial services, logistics or design leaving just $5 \%$ of manufacturing jobs dedicated to actually producing a tangible good for export (The Economist, 2005). This steady decline can in part be attributed to an increase in productive output as manufacturing processes are increasingly automated, as well as the possibility of changing domestic demand factors. However, millions of those lost jobs is due to cost reducing measures that sent American manufacturing jobs overseas where the cost of labor was substantially lower. In addition, many millions more were lost as a result of a growing manufacturing trade deficit spurred by short sighted economic policies and an over confidence in service export surpluses. In fact, growing net in manufacturing imports accounts for some $59 \%$ of manufacturing job loss since 1998 and 34\% since 2000 (Bivens, 2004).

The United States' faith in the service industry's “trade-off” power, while possible in theory, has been misplaced as it has ignored the reality that the service export surplus represents a small percentage of the manufacturing trade deficit. Furthermore, its rate of growth is nominal in proportion to that of the growth rate of the manufacturing trade deficit (Bivens, 2004). Simply put, the last 50 years of decline in US manufacturing and faith in the service industry has seen the US purchasing more than it produces. Further compounding the economic impact of this imbalance, consider that the average manufacturing job pays nearly $\$ 25,000$ more per year on average over service sector positions while, in many cases, also providing health and pension benefits. Clearly, the loss of wages and benefits that previously afforded a middle class lifestyle is difficult to replace through service sector employment (Alliance for American Manufacturing, 2010). Another key concept not to be overlooked is the "multiplier effect", which in short provides that investing in a sector fuels regional or national economic development through additional job creation. For instance, it is estimated that every direct manufacturing job in the United States supports 2.9 indirect positions in associated activities such as finance, 
logistics or transportation (Apollo Alliance, 2009). In contrast, estimations for each service sector position range from 0.9 to 1.5 supported jobs (Alliance for American Manufacturing, 2010). Clearly the net impact of lost manufacturing jobs in the United States has far reaching implications.

The United States is not alone in experiencing a long range decline in manufacturing jobs, as major competitors in Europe and Asia have undergone the same. However, these countries have kept a more healthy percentage of their GDP in manufacturing by growing high tech manufacturing jobs, even while continuing to outsource commodity manufacturing to leverage lower costs (Raveche, 2009). Our competitors have been successful in this strategy, in large part, due to a more robust respect for the limits of the service industry. However, an acute awareness of the need for an educational system designed to support the future of competing in the global manufacturing arena is more likely a better explanation. As it turns out, America has been sleeping while the world has been studying.

\section{Current Problems}

In order to be successful in the new manufacturing reality, the United States must strive for significant improvements in our performance in the fields of mathematics, science and technology education. A 2007 study, commissioned by the US Department of Education and conducted by the National Center for Educational Statistics, found that in mathematics 4th grade students in US lagged behind the UK, Japan and Russia by 7\%, $14 \%$ and $4 \%$ respectively when measured against the advanced international benchmark. The same study showed that 4 th grade students in US fared slightly better being edged out by UK students by a $2 \%$ margin while barely surpassing Japan and Russia by a margin of 1\% and 2\% respectively (Miller, 2007). The same study measured 15 year old students' combined math and science literacy at the most advanced level and found that the United States ranked last, tied with Italy and Russia, among the G-8 nations trailing Japan, Canada, France and Germany by 6\%, $3 \%, 1 \%$ and $2 \%$ respectively (Miller, 2007).

Looking further into the global competitive picture, scores from the 2006 Program for International Student Assessment (PISA), an exam administered once every three years to test students' ability to apply math and science concepts to real world problems, showed that US High School students scored 24th and 17th respectively of 30 countries (Glod, 2007). When these facts are combined with the knowledge that the United States spent the highest percentage of GDP of the compared countries, at 7\%, on education at the combined levels, it becomes clear that something in the educational system is broken. In particular, when one considers that the United States ranks first and second in math and science teachers' average first year compensation respectively (Miller, 2007).

While the United States spends significantly more as a percentage of GDP on post secondary education than any of the compared nations, it is too little and too late to make an impact on math and sciences. Just $17 \%$ of post secondary degrees awarded in the United States, in the years covered, were in the fields of math, science or engineering, a number $13 \%$ behind manufacturing competitor Germany and $4 \%$ behind Japan (Miller, 2007). It is little wonder that these two competitors have been able to keep more than one third of their GDP in manufacturing than that of the United States.

\section{Current Needs and Strategies}

Today, only 21 states have policies in place aligning high school graduation requirements with college and 
workplace expectations. Furthermore, just 10 States have developed college and career readiness assessment systems integral to identifying strengths and weaknesses in both students and the system in which they are educated (Institute of Education Sciences, 2009). These findings, coupled with US students' below average test scores, despite higher teacher compensation in math and science, and our nation's continued manufacturing decline clearly indicate the United States needs a new strategy to align its education system with real world demands.

The first step towards a new strategy will foster a sense of national purpose focused on achieving the goal of economic recovery through education reform. Such reform must address the disconnect between what is being taught in our schools and what the world requires of its skilled workforce. Most importantly, this reform should be designed specifically to position the United States for successful creation of well paying and high economic value manufacturing jobs.

First, many of our European and Asian competitors enjoy enrollment rates for Pre-K programs of more than $50 \%$, while only $23 \%$ of US student begin their career at this level. Essentially, our competitors have a significant "head start" in the race for academic excellence. One of our national goals should be to make Pre-K enrollment accessible and affordable to families by greatly expanding the involvement of public school districts in these programs. At the K-7 level, there must be a paradigm shift away from focusing on liberal arts and humanities to a heavier emphasis on math, science and technology. The certification process for teachers at this level needs to become more rigorous, requiring a greater amount of college course work in math and science and scoring standards more heavily weighted toward these academic areas. From an administrative stand point, curriculum must focus much more heavily upon critical thinking and problem solving skills, two areas US high school students struggle tremendously. Specifically, targeted funding is required to accomplish this necessary curriculum over-haul, as well as to provide for the continued education of our nation's teachers. Educators at this level must be required to complete scheduled training to continually update their skill sets, effectiveness, evaluation techniques, planning abilities and keep in touch with the real world applications of math and science in industry. Once these steps are accomplished, our nation's high school students will have been provided with a solid foundation from which to build upon at the next level of education.

It should be completely unacceptable to every American that less than one fifth of states have policies in placing establishing college and career readiness assessment programs in their high schools. Additional funding to bring every state up to speed within the next 2 years should be a high priority and every effort should be made by the federal government to compel compliance. Funding should also be allotted for secondary school math and science teachers to receive mandatory continued education tailored in a similar way as that suggested for primary school teachers, but a heavier emphasis should be placed on cooperation with universities and employers to gain insight into what will be asked for students at the next level. Time spent in manufacturing facilities observing the day to day application of disciplines such as algebra, calculus, geometry, physics, chemistry and biology will enhance an educator's ability to formulate lesson plans that value practice as much as theory. Furthermore, increased cooperation between high school and university faculty will foster a sense of cooperation giving high school students access to up to date information, and an opportunity to refine their career interests. In addition, it may be helpful to consider the possibility of providing additional incentives to secondary school teachers whose students consistently score above established international benchmarks in literacy in math, science and technology. This type of program would provide for healthy competition between districts and States that will 
serve to maximize the return on the nations increased investment in education, while providing an outstanding example to students seeking to excel at the next level.

Finally, reform at the post secondary level should involve increased state and federal funding for programs specifically designed to perform research and development in the fields of industrial design, engineering, materials, energy distribution and alternative energy (Raveche, 2009). These are the areas in which the United States has the opportunity to excel and they represent the future of high value manufacturing jobs. Grants should be awarded strictly on a competitive basis, again to foster the competitive spirit necessary for success in the global market. Awarding funds like this way will inevitably foster greater opportunity for community involvement, secondary school-university cooperation, and attract the attention of businesses seeking new innovations and a skilled workforce.

In fact, the involvement of business in the rejuvenation of math, science and technology education should be deliberately grown and facilitated through federal incentives. Industry investment in joint research and development projects with our nation's universities can provide a number of invaluable benefits. First, this type of joint venture will facilitate a program design that allows for faculty to spend time working in the field focused specifically on how their discipline relates to manufacturing. By virtue of this practical experience, educators will have a more balanced perspective from which to present information and additional tools at their disposal for educating students. Second, this cooperative relationship between industry and universities will give the industry significant input into the skill sets, knowledge and abilities to be developed and mastered for success in a given field of study. The net effect of which will allow for new innovations without losing sight of manufacturing excellence and the competitive "here and now" (Raveche, 2009). Finally, as these cooperative relationships begin to flourish and provide real world results with real world profits, it has the potential to create a cycle of reinvestment in our nation's university students. As the innovations born of these partnerships become patents and new products to bring to the global market, valuable high tech manufacturing jobs are created. With each one it moves us one step closer to a stronger sustainable economy.

\section{References}

Alliance for American Manufacturing. (2010). Issues. Retrieved March 28, 2010, from http://www.americanmanufacturing.org/issues/economic/

Apollo Alliance. (2009). Make it in America: The Apollo green manufacturing plan. San Fransisco CA: Apollo Alliance.

Bivens, J. (2004). Shifting blame for manufacturing job loss: Effect of rising trade deficit shouldn't be ignored. Washington D.C.: Economic Policy Institute.

Bornemann, J. (2009, November-December). Want jobs? Get manufacturing. Textile World, 59(6), 7.

Glod, M. (2007, December 5). U.S. teens trail peers around world on math-science test. Washington Post .

Institute of Education Sciences. (2009). State high school policies for college and work readiness, by state: 2009. National Center for Educational Statistics, U.S. Department of Education. Retrieved March 29, 2010 from: http://nces.ed.gov/programs/statereform/tab1_8.asp

Kanell, M. (2009, December). Manufacturing a path to recovery: Rise of service sector led to decline of this engine of jobs, wealth creation. The Atlanta Journal-Constitution, A1.

Miller, D. S. (2007). Comparative indicators of education in the united states and other g-8 countries: 2006. Washington D.C.: National Center for Education Statistics, Institute of Education Sciences, U.S. Department of Education.

Raveche, H. (2009, January 31). Education and economic recovery. Retrieved March 17, 2010 from http://www.forbes.com/2009/01/30/education-manufacturing-research-opinions-contributors_0131_hal_raveche.html

The Economist. (2005, October 1). Industrial metamorposis. The Economist, 69-70. 